\title{
BIOEDUSCIENCE
}

ISSN: 2614-1558

http://journal.uhamka.ac.id/index.php/bioeduscience

\section{Response of Seed Bio-invigoration with Plant Growth Promoting Rhizobacteria (PGPR) on Growth and Productivity of Gogo Rice}

\author{
Fitriani $^{1 *}$, Yulida Amri², Syamsul Bahri ${ }^{3}$ and Fara Nadilla ${ }^{1}$
}

1Program Studi Biologi, Fakultas Teknik, Universitas Samudra, Jl, Prof. Dr. Syarief Thayeb, Meurandeh, Langsa Lama, Langsa City, Aceh, Indonesia, 22415

2Program Studi Kimia, Fakultas Teknik, Universitas Samudra, Jl, Prof. Dr. Syarief Thayeb, Meurandeh, Langsa Lama, Langsa City, Aceh, Indonesia, 22415

${ }^{3}$ Program Studi Agroteknologi, Fakultas Pertanian, Universitas Samudra, Jl, Prof. Dr. Syarief Thayeb, Meurandeh, Langsa Lama, Langsa City, Aceh, Indonesia, 22415

* Corespondent Email: fitriani@unsam.ac.id

\section{ARTICLE INFO}

Article history:

Received: 16 Okt 2020

Accepted: 17 Mar 2021

Published: 30 April 2021

\section{Keywords:}

Biomatriconditioning

Gogo rice

Growth

Productivity

\section{A B S T R A C T}

Background: Gogo rice is a type of rice that can be cultivated on dry land with a yield productivity level of 2.57 tons / Ha. So it is necessary to make efforts to increase the growth and productivity of gogo rice through seed bio-inviguration using PGPR. The purpose of this study was to determine the effect of beni bioinviguration techniques using PGPR on the growth and productivity of gogo rice. Method: This study used a RAK consisting of 7 treatments and 5 replications. Data analysis used ANOVA at the 5\% confidence level and continued with the BNT test. Result: The results showed that the use of biomatriconditioning medium integrated with PGPR could increase the stem height of upland rice by $104.2 \mathrm{~cm}, 117 \mathrm{~cm}$, and 133.3, the number of tillers were 7, 13 and 15 at the age of 8,10 , and 12 MST. In addition, it can also increase the number of panicles, the length and weight of 100 grains of $14,22.6 \mathrm{~cm}$ and 2.1 grams. Conclusion: the use of biomatriconditioning medium integrated with PGPR can increase the growth and productivity of gogo rice.

Respon Bioinvogurasi Benih dengan Plant Growth Promoting Rhizobacteria (PGPR) terhadap Pertumbuhan dan Produktivitas Padi Gogo

\section{A B S T R A K}

Backgrond: Padi gogo sebagai salah satu jenis padi yang dapat dibudidayakan dilahan kering dengan tingkat produktivitas hasil sebesar 2,57 ton/ Ha-1. Sehingga perlu dilakukan upaya peningkatan pertumbuhan dan produktivitas padi gogo melalui bioinvigurasi benih dengan menggunakan PGPR. Tujuan penelitian ini untuk mengetahu pengaruh teknik bioinvigurasi beni dengan meengunakan PGPR terhahadap pertumbuhan dan produktivitas padi gogo. Metode: Penelitian ini menggunakan RAK yang terdiri dari 7 perlakuan dan 5 ulangan. Analisis data menggunakan ANOVA pada taraf kepercayaan 5\% dan dilanjutkan dengan uji BNT. Hasil: Hasil penelitian menunjukkan bahwa penggunaan medium biomatriconditioning arang sekam yang diintegrasikan dengan PGPR dapat meningkatkan tinggi batang tanaman padi gogo sebesar sebesar 104,2 cm, $117 \mathrm{~cm}$, dan 133,3, jumlah anakan sebesar 7, 13 dan 15 pada umur 8, 10, dan 12 MST. Selain itu juga dapat meningkatkan jumlah malai, panjang nalai dan berat 100 gabah sebesar 14 , 22,6 cm dan 2,1 gr. Kesimpulan: Penggunaan medium biomatriconditioning arang sekam yang diintegrasikan dengan PGPR dapat meningkatkan pertumbuhan dan produktivitas tanaman padi gogo. 


\section{Introduction}

Rice gogo can have a yield productivity level of 2.57 tonnes/ Ha cultivated on dry land. This shows that the productivity of gogo rice production is still very low when compared to the general level of 4.76 tonnes / Ha with a population of 16 plants per $\mathrm{m} 2$ (Sumardi, 2017). This is due to low soil $\mathrm{pH}$, aluminium poisoning, lack of calcium, magnesium and phosphorus as important elements that support the growth of rice (Dariah et al., 2014). In addition, it is also caused by the quality and adaptability of the seeds which are not good. Therefore, it is necessary to make alternative efforts to increase rice productivity through the use of superior seeds physically, physiologically and genetically that can adapt to various environments. If the rice seeds used do not have high quality, the plants will not produce high yields (Fitriani et al., 2020). One of the efforts that can be developed is seed bio-invigoration using PGPR which is expected to increase the growth and productivity of gogo rice.

Bio-invigoration is a process of improving the biochemical and physiological processes of seeds to increase the synchronization and speed of seed growth using low matrix potential media (matriconditioning) integrated with PGPR. PGPR is a group of Rhizhobacteria consisting of Bacillus subtilis, Pseudomonas fluorescens, Trichoderma harzianium, and Tricoderma viride. PGPR acts as a biofertilizer, biostimulant and bioprotectant against plants (Ruzzi \& Aroca, 2015). In addition, Juanda (2005); Husen (2016) reported that PGPR is a group of Rhizobacteria which has a role to increase plant growth either directly or indirectly. This is because of Rhizobateria sp. can produce the hormone IAA (Gholami et al., 2009), minerals, antifungal, and antibacterial. Thus the aim of this study is expected to increase the growth and productivity of gogo rice.

\section{Methods}

This research was conducted in July-August 2020 at the Green House of Samudra University. The samples used were gogo rice seeds with a total of 35 samples. The materials used were seeds of gogo rice, red brick powder, husk charcoal powder, compost and PGPR. The tools used were evaporators, ovens, nursery boxes and pots measuring $30 \times 30 \mathrm{~cm}$. The experimental used a randomized block design (RAK) with 7 experimental groups and 5 replications so that the number of samples (gogo rice) used was 35. The grouping uses the RAK because the environmental conditions are less homogeneous, so it is expected to reduce the number of squares of errors, so as to increase the level of accuracy. The experimental group used were: positive control (G1), negative control (G2), dehydration (G3), matrioconditioning with red brick powder (G4), matrioconditioning with husk charcoal powder (G5), biomatriconditioning using husk charcoal powder and PGPR (G6), biomatriconditioning with red rock powder and PGPR (G7).

The Procedure with dehydration treatment was carried out by soaking the seeds in free water for 24 hours and then drying them so that they reach their original weight. The seed treatment by matriconditioning was carried out by mixing the seeds with the solid media of husk charcoal powder or red brick powder. Seed treatment with biomatriconditioning used the same procedure as the matriconditioning treatment. However, rice seeds were first soaked using PGPR for 24 hours. After treatment, the seeds were cleaned and dried, then the seeds were ready for use. Seeds of gogo rice were sterilized by soaking with $2 \%$ sodium hypochlorite solution for 5 minutes, then rinsing 3 times with sterile water and drying for one hour. Furthermore, the seeds were soaked again for 24 hours using 0.2 grams of rhizobacteria which have been dissolved with $100 \mathrm{~mL}$ sterile water. Then the Rice Gogo seeds were ready for use in seed treatment. Rhizobacteria used in the form of PGPR (Sutariati \& Safuan, 2012). Furthermore, seeds of gogo rice were sown in the nursery according to the treatment. The rice seeds were watered slightly once in 46 hours. After the Rice Gogo seeds grow and were 14 days old, the rice seeds were ready to be transferred to the planting medium. The planting medium used was compost and soil with a ratio (1:3). Furthermore, the planting medium was left for one week in order for the compost to blend with the soil. Furthermore, rice plants that were 14 days old were transferred to the planting medium. For every 1 pot filled with one rice plant. Weed removal was done manually by removing weeds that grow around gogo rice.

The parameters observed were stem height, number of tillers, number of panicles, panicle length, and weight of 100 filled grains. Stem height and number of tillers were collected when the rice plants were 8 weeks, 10 and 12 WAP. Meanwhile, plant productivity data was taken when the rice cultivation has completed its life cycle (16 WAP). Furthermore, the research data were analyzed using ANOVA (5\% significance) and continued with the Least Significant Difference Test (LSD). The criteria for testing the hypothesis are: Ho is accepted if the value of $\mathrm{F}$ count $<\mathrm{F}$ table and Ho is rejected if the $\mathrm{F}$ count value $>\mathrm{F}$ table (Gomez \& Gomez, 2010).

\section{Results}

The results of analysis of variance (ANOVA) showed that there was an effect of seed bio-invigoration integrated with PGPR on stem height, number of tillers, number of panicles, panicle length and weight of 100 gogo rice 


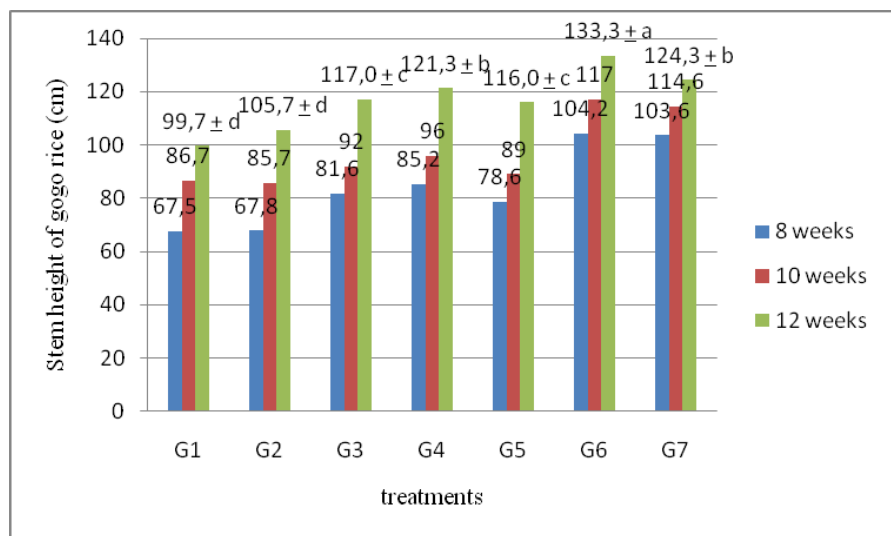

Figure 1. Stem height of gogo rice after treatment

Figure 1 shows that the seed bio-invigoration treatment integrated with PGPR can increase the stem height of gogo rice. The use of husk charcoal biomatriconditioning medium integrated with PGPR (G6) can increase the height of rice stalks by $104.2 \mathrm{~cm}, 117 \mathrm{~cm}$, and $133.3 \mathrm{~cm}$ at the age of 8,10 and 12 WAP.

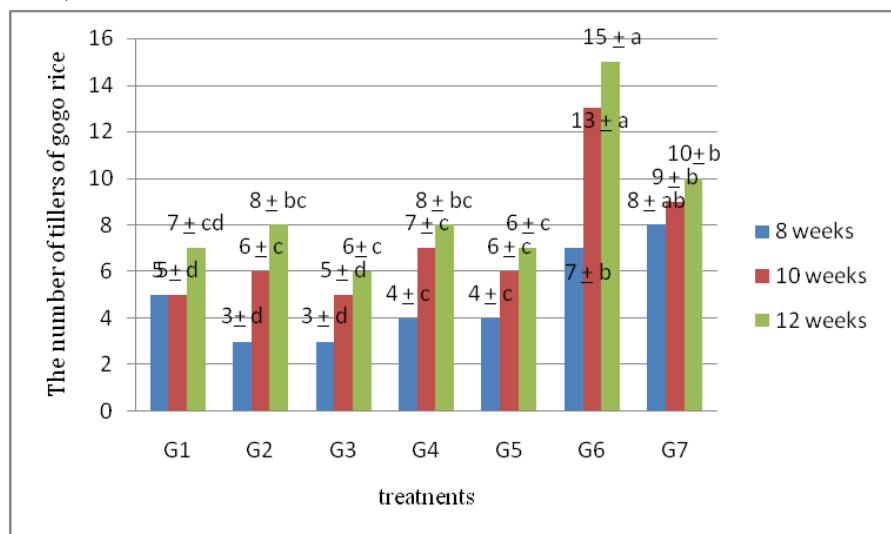

Figure 2. The number of tillers of gogo rice after treatment

Figure 2 shows that seed bio-invigoration treatment integrated with PGPR can increase the number of tillers of gogo rice. The use of husk charcoal biomatriconditioning medium integrated with PGPR (G6) can increase the number of tillers of rice by 7,13 and 15 at the age of 8,10 and 12 MST.

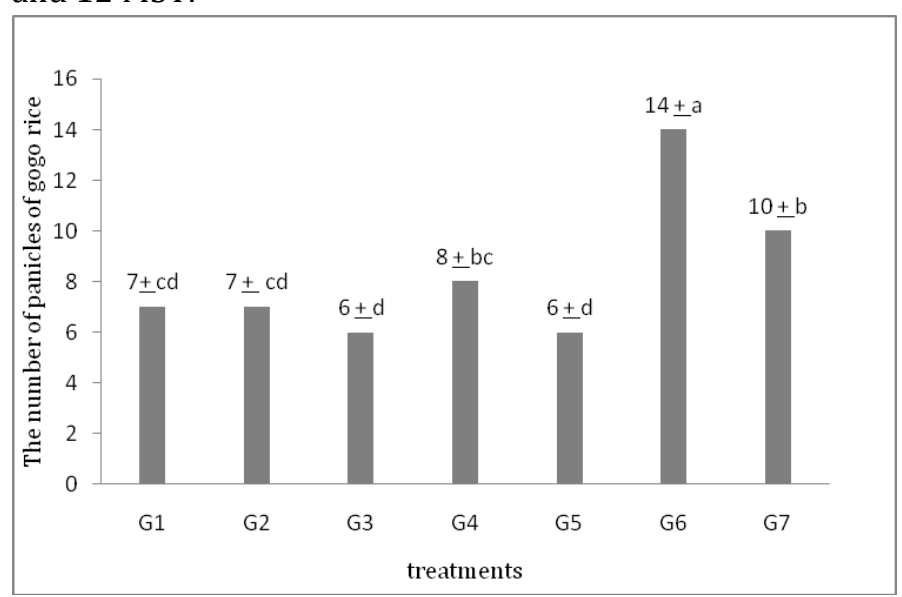

Figure 3. The number of panicles of gogo rice after treatment
Figure 3 shows that seed bio-invigoration treatment integrated with PGPR can increase the number of panicles of gogo rice. The use of husk charcoal biomatriconditioning medium integrated with PGPR (G6) can increase the number of panicles by 14 panicles.

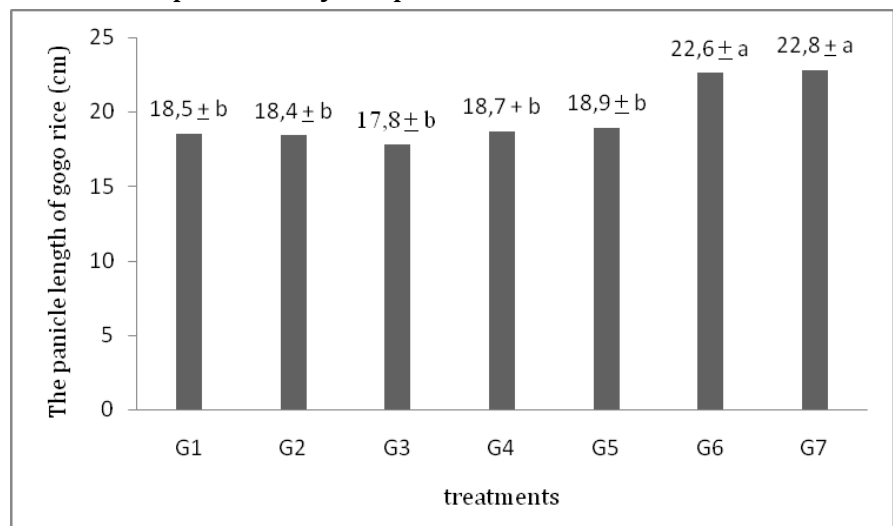

Figure 4. The panicle length of gogo rice after treatment

Figure 4 shows that the seed bio-invigoration treatment integrated with PGPR can increase the panicle length of gogo rice. The use of biomatriconditioning medium which was integrated with PGPR (G6) and (G7) can increase the length of rice plant panicles by $22.6 \mathrm{~cm}$ and $22.8 \mathrm{~cm}$.

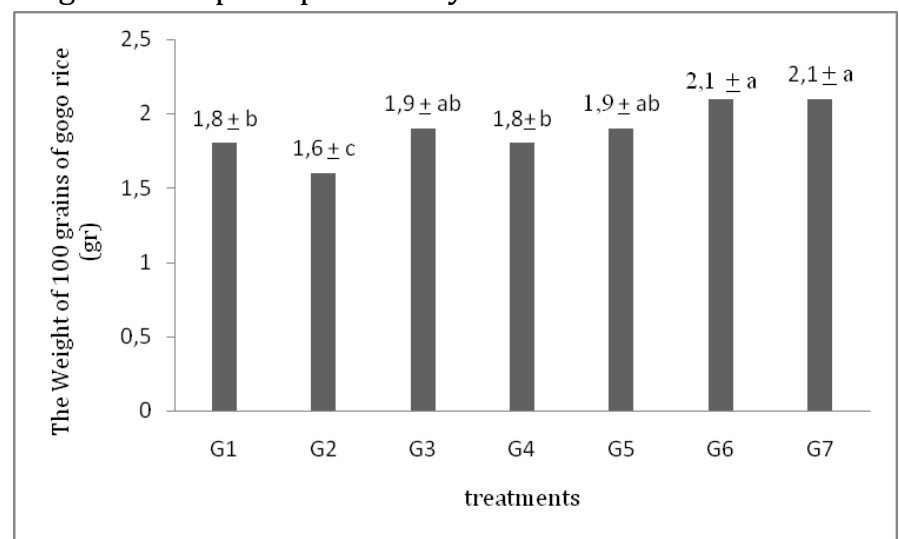

Figure 5. The Weight of 100 grains of gogo rice after treatment

Figure 5 shows that the seed bio-invigoration treatment integrated with PGPR can increase the weight of 100 seeds of gogo rice. The use of husk charcoal biomatriconditioning medium integrated with PGPR (G6) and the use of red brick powder biomatriconditioning medium integrated with PGPR (G7) can increase the weight of 100 seeds by 2.1 gram. However, it was not significantly different from the use of dehydra (G3) and the use of the medium with husk charcoal powder (G5).

\section{Discussions}

Based on the results of the study, it was shown that there was an effect of the use of seed bio-invigoration integrated with PGPR on the growth and productivity of gogo rice. This is because of the PGPR which is integrated into rice seeds during seeding contains various types of bacteria which are very beneficial for the growth of gogo 
rice. The types of bacteria contained in PGPR are Bacillus subtilis, Pseudomonas fluorescens, Trichoderma harzianium, Trichoderma sp. and Trichoderma viride. PGPR acts as a biofertilizer, biostimultant and bioprotectant against plants.

The use of husk charcoal biomatriconditioning medium integrated with PGPR can increase the stem height of gogo rice. This is because of PGPR which is integrated with the matriconditioning of husk charcoal powder can be associated so that it can increase nutrient mobilization and can stimulate the synthesis of hormones that play a role in plant growth (Ashrafuzzaman et al., 2009). In this case, Wangadi et al. (2018) reported that the use of matriconditioning media for husk charcoal powder and red brick causes the seeds to absorb relatively small amounts of water. This is because of a lot of water is absorbed by the media so that the metabolic process of the seeds can occur optimally. In addition, Adesemoye et al. (2008) reported that the use of biological fertilizers in the form of rhizobacteria or rhizosphere bacteria will produce phytohormones in the form of auxins, cytokinins and gibberellins which can stimulate plant growth. IAA is an active form of the auxin hormone found in plants and plays a role in increasing cell development, spurring growth and increasing enzyme activity (Arshad \& Frankenberger, 1993). The large potential of PGPR and husk charcoal powder matriconditing results in integration between PGPR and the matriconditioning medium so that it will produce optimal plant height growth.

The use of husk charcoal biomatriconditioning medium integrated with PGPR can increase the number of tillers and the number of panicles of gogo rice. This is because of PGR can increase the formation of the hormones auxin, cytokinins and gibberellins. Cytokinins play a role in cell division and induce shoot formation (Davis, 2005). In addition, PGPR (Plant Growth Promotion Rhizobacteria) can play a role in nitrogen fixation and activate plant disease resistance systems. The high nitrogen content in the planting medium can increase the number of tillers by increasing the endogenous cytokinin content and inhibiting endogenous strigolactone in gogo rice. In plants, nitrogen in the planting medium can increase the expression of IPT3, IPT5, and CYP735A2 genes in the roots so that the endogenous cytokinin content increases. In addition, PGPR also plays a role in dissolving phosphate so that the availability of phosphate in plants can inhibit the expression of D10, D17, D27, and MAXI-related CYP711A genes in the roots so that it will inhibit strigolactone activity (Domagalska \& Leyser, 2011). An increase in the number of tillers will be followed by an increase in the number of panicles so that it is hoped that it can increase plant productivity.

The use of biomatriconditioning medium for husk charcoal and red brick powder integrated with PGPR can increase panicle length and weight of 100 grains filled with Padi Gogo. The increase in the length is caused by PGPR that contains several types of bacteria that are capable of producing various types of hormones that play a role in spurring plant growth. In this case, Ahemad \& Kibret (2014) reported that PGPR is a microbe that is around the roots that are involved directly or indirectly in increasing plant growth and development. In addition, Khalimi \& Wirya (2012) also reported that PGPR was able to regulate the concentration of endogenous hormones in plants, both IAA, cytokinins, ethylene and gibberellin, and reduce the level of heavy metal poisoning. Thus the many roles of PGPR in increasing the content of plant endogenous hormones, resulting in an increase in the length of rice panicles when compared to treatment without the use of PGPR. The one of the PGPR group is Bacilus $s p$ which was able to stimulate plant growth by stimulating lateral growth, so that water absorption and nutrients are more optimal (Fajaruddin et al., 2020).

The increase in weight of 100 filled grains of Padi Gogo was due to the fact that PGPR which was integrated with the biomatriconditioning medium of husk charcoal and red brick powder was able to stimulate and improve the quality of Padi Gogo yields. In this case, Handayani et al. (2019) reported that biomatriconditioning treatment with rhizobacteria was able to increase the weight of 1000 grains and the weight of sorghum panicles. In addition, the PGPR that is applied is able to provide nutrients from initially unavailable to available and capable of producing growth hormones in the form of IAA, cytokinins and gibberellins. cytokinins. Cytokinins are known to play an important role in the transport of photosynthate products into the cavity which involves transportation through simplas and apoplasts (Silverman et al., 1998; Vacheron et al., 2013). Cytokinins can increase the absorption ability of sucrose by stimulating the OsCINI gene to increase the activity of the invertase enzyme which plays a role in filling seeds and the OsSUT gene which activates the sucrose transporter (Lee \& Huang, 2013). PGPR consists of several bacteria that play a role in dissolving phosphate which is used to stimulate the growth of roots, fruit, improve quality and strengthen resistance to pests and diseases so that the growth and productivity of gogo riceare optimal. In addition, Nafiah \& Suryanto (2019) stated that the use of Rhizobacteria can increase nitrogen content and nitrogen uptake in plants, resulting in increased formation of filled grain.

\section{Conclusions}

There is an effect of using seed bio-invigoration using PGPR on stem height, number of tillers, panicle length, number of panicles and weight of 100 filled grains, the use of husk charcoal biomatriconditioning medium integrated with PGPR can increase stem height by $104.2 \mathrm{~cm}, 117 \mathrm{~cm}$ 
133.3, the number of tillers were 7, 13 and 15 at the age of 8,10 , and $12 \mathrm{MST}$. In addition, it can also increase the number of panicles, the length and weight of 100 grains by $14,22.6 \mathrm{~cm}$ and 2.1 grams at the age of 16 WAP.

\section{Declaration statement}

The authors reported no potential conflict of interest.

\section{Acknowledgement}

The author would like to thank Samudra University for providing research funding through the grant of Penelitian Dasar Unggulan (PDU) with Contract No. 522/UN.54.6 /PG/2020.

\section{References}

Adesemoye, A. O., Obini, M., \& Ugoji, E. O. (2008). Comparison of plant growth-promotion with Pseudomonas aeruginosa and Bacillus subtilis in three vegetables. Brazilian Journal of Microbiology, 39(3), 423-426. https://doi.org/10.1590/S1517-83822008000300003

Ahemad, M., \& Kibret, M. (2014). Mechanisms and applications of plant growth promoting rhizobacteria: Current perspective. Journal of King Saud University - Science, 26(1), 1-20. https://doi.org/10.1016/j.jksus.2013.05.001

Arshad, M., \& Frankenberger, J. (1993). Microbial production of plant growth regulators. p. 307-347. In F.B. Meeting, Jr. (Ed.). Soil Microbial Ecology. Applications in Agricultural and Environmental Management.

Ashrafuzzaman, M., Hossen, F. A., Razi Ismail, M., Hoque, A., Islam, M. Z., Shahidullah, S. M., \& Meon, S. (2009). Efficiency of plant growth-promoting rhizobacteria (PGPR) for the enhancement of rice growth. African Journal of Biotechnology, 8(7), 1247-1252.

Dariah, A., Kartiwa, B., Sutrisno, N., Suradisastra, K., Sarwani, M., Soeparno, H., \& Pasandaran, E. (2014). Prospek Pertanian Lahan Kering dalam Mendukung Ketahanan Pangan. Balitbangtan.

Davis. (2005). Plant Hormone. Biosynthesis, Signal Transduction, and Action. Kluwer Academic Publishers.

Domagalska, M. A., \& Leyser, O. (2011). Signal integration in the control of shoot branching. In Nature Reviews Molecular Cell Biology (Vol. 12, Issue 4, pp. 211-221). Nat Rev Mol Cell Biol. https://doi.org/10.1038/nrm3088

Fajaruddin, Karmiati, Aulya, W., Fitriani, \& Persada, A. Y. (2020). The effect of silica liquid fertilizer from straw and formulation of bacillus sp for rice growth (Oryza sativa L.) and tolerance to fungi Pyricularia oryzae Cav. IOP Conference Series: Materials Science and Engineering, 725(1), $012067 . \quad$ https://doi.org/10.1088/1757899X/725/1/012067

Fitriani, Mardina, V., Fadhliani, \& Baiduri, N. (2020). Isolation and identification of pathogen fungi in the varieties of local rice, Aceh-Indonesia. IOP Conference Series: Materials Science and Engineering, 725(1), 012070. https://doi.org/10.1088/1757-899X/725/1/012070

Gholami, A., Shahsavani, S., \& Nezarat, S. (2009). Effect of Pgpr on Germination,Seedling Growth and Yeild of Maize. World Academy of Science, Engineering and Technology, 19-24.

Gomez, K., \& Gomez, A. (2010). Prosedur Statistik untuk Penelitian Pertanian.Edisi Kedua. In Diterjemahkan oleh Endang
Sjamsuddin dan Yustika S. Baharsjah (pp. 98-100) Universitas Indonesia.

Handayani, F., Sutariati, G. A. K., \& Madiki, A. (2019). Biomatriconditioning Benih dengan Rizobakteri untuk Meningkatkan Pertumbuhan dan Hasil Tanaman Sorgum (Sorghum bicolor L.). Agrotekma: Jurnal Agroteknologi Dan Ilmu Pertanian, 4(1),

https://doi.org/10.31289/agr.v4i1.2949

Husen, E. (2016). Screening Of Soil Bacteria For Plant Growth Promotion Activities In Vitro. Indonesian Journal of Agricultural Science, $4(1), \quad 27$ https://doi.org/10.21082/ijas.v4n1.2003.p27-31

Juanda, J. (2005). Screening of soil bacteria for plant growth promoting activities in vitro. J Agric Sci, 4, 27-31.

Khalimi, K., \& Wirya, G. N. A. S. (2012). Pemanfaatan Plant Growth Promoting Rhizobacteria Untuk Biostimulants Dan Bioprotectants. ECOTROPHIC: Jurnal Ilmu Lingkungan (Journal of Environmental Science), 4(2).

Lee, S. T., \& Huang, W. L. (2013). Cytokinin, auxin, and abscisic acid affects sucrose metabolism conduce to de novo shoot organogenesis in rice (Oryza sativa L.) callus. Botanical Studies, 54(1). https://doi.org/10.1186/1999-3110-54-5

Nafiah, V. I., \& Suryanto, A. (2019). Kajian PGPR (Plant Growth Promoting Rhizobacteria) Pada Berbagai Tingkat Aplikasi Nitrogen Terhadap Padi Gogo (Oryza Sativa L.) Varietas Situ Bagendit. Jurnal Produksi Tanaman, 6(7), 1588-1596. https://doi.org/10.21176/PROTAN.V6I7.815

Ruzzi, M., \& Aroca, R. (2015). Plant growth-promoting rhizobacteria act as biostimulants in horticulture. In Scientia Horticulturae (Vol. 196, pp. 124-134). Elsevier. https://doi.org/10.1016/j.scienta.2015.08.042

Silverman, F. P., Assiamah, A. A., \& Bush, D. S. (1998). Membrane transport and cytokinin action in root hairs of Medicago sativa. Planta, 205(1), 23-31. https://doi.org/10.1007/s004250050292

Sumardi, S. (2017). Produktivitas Padi Sawah Pada Kepadatan Populasi Berbeda. Jurnal Ilmu-Ilmu Pertanian Indonesia, 12(1), 49-54. https://doi.org/10.31186/jipi.12.1.49-54

Sutariati, G. A. K., \& Safuan, L. O. (2012). Seed Treatment using Rhizobacterium Improved Seed Quality and Yield of Hot Pepper (Capsicum annuum L.). Jurnal Agron Indonesia, 40(2), 125-131.

Vacheron, J., Desbrosses, G., Bouffaud, M. L., Touraine, B., MoënneLoccoz, Y., Muller, D., Legendre, L., Wisniewski-Dyé, F., \& Prigent-Combaret, C. (2013). Plant growth-promoting rhizobacteria and root system functioning. Frontiers in Plant Science, 4(SEP). https://doi.org/10.3389/fpls.2013.00356

Wangadi, S., Ayu, G., Sutariati, K., \& Khaeruni, A. (2018). Analysis Of Seed Bio-Invigoration Technique And Leisa To Increase The Growth Of Local Upland Rice At Screen House. Jurnal Berkala Penelitian Agronomi, 6(2), 1-10. 